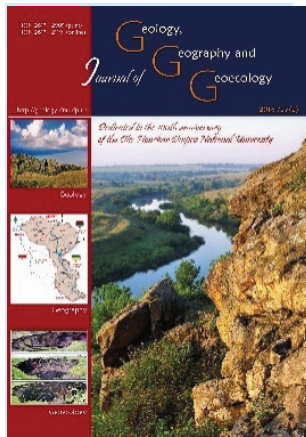

\section{Journal of Geology, Geography and Geoe- cology}

Journal home page: geology-dnu-dp.ua
Journ.Geol.Geograph. Geoecology, 27(3), 537-545 doi: $10.15421 / 111878$

I.V. Zhiltsova, M.V. Ruzina, M.L. Malova,

N.V. Bilan, O.A. Tereshkova, A.S. Gardysh

Journ.Geol.Geograph.Geoecology, 27(3), 537-545

\title{
Analysis of the spatial patterns in localization of gold mineralization relative to the system of deep faults in the Chortomlyk greenstone structure of the Ukrainian shield
}

\author{
I.V. Zhiltsova ${ }^{1}$, M.V. Ruzina ${ }^{1}$, M.L. Malova ${ }^{2}$, N.V. Bilan ${ }^{1}$, O.A. Tereshkova ${ }^{1}$, A.S. Gardysh ${ }^{1}$ \\ ${ }^{I}$ Dnipro University of Technology,Dnipro,Ukraine,e-mail: Zhiltsova.Irena@gmail.com \\ ${ }^{2}$ State «Enterprise Pivdenukrgeologia»,e-mail: mamarusja@ukr.net
}

Received 18.10.2018;

Received in revised form 27.11.2018;

Accepted 29.11.2018

Abstract. The results of analysisof the patterns of the spatial relationship between hydrothermal gold ore formations and the zones of metasomatites and systems of deep faults within the Chortomlyk greenstone structure of the Middle Pridniprovie megablock in the Ukrainian Shield are given. As a result of studying the localization conditions of gold mineralization, it was established that the gold-bearing mineralization is confined to tectonically fractured zones and is localized among metasomatically altered rocks. The hydrothermal series of metasomatites in the Chortomlyk greenstone structure is represented by greisens, propylites, amphibole-carbonate metasomatites and listvenite-berezites. The mineralization of $\mathrm{Au}$ and $\mathrm{Mo}$ is associated with metasomatites of the greisen type. The study of spatial relationship between the fields of metasomatites and the gold mineralization and zones of deep faults revealed that the closest relationship is expressed with systems of faults with azimuths of $0^{\circ}$ and $270^{\circ}, 17^{\circ}$ and $287^{\circ}, 77^{\circ}$ and $347^{\circ}$. The results of the studies allowed us to develop a new prospecting criterion, which, in turn allows us to state that the gold mineralization within the Chortomlyk greenstone structure is spatially confined to metasomatites related to the schistosity, fracture, millonitization, and cataclase zones with high content of sulphide mineralization. These zones are localized in nodes of intersecting faults of the first order of the system $77^{\circ}$ and $347^{\circ}$ with discontinuous violations of high orders of azimuths of $0^{\circ}$ and $270^{\circ}, 17^{\circ}$ and $287^{\circ}$. The results of the research can be used to develop a set of predictive criteria and the allocation of promising sites of hydrothermal mineralization of gold within the Chortomlyk greenstone structure of the Middle Pridniprovie megablock in the Ukrainian shield.

Keywords: deep faults, metasomatite, gold mineralization, greenstone structure, Middle Pridniprovie megablock, hydrothermal formations.

\section{Аналізпросторовихзакономірностейлокалізаціїзруденіннязолота відносносистемглибиннихрозломівумежахЧортомлицькоїзеленокам'яної структуриУкраїнськогощита}

\author{
І.В. Жильцова ${ }^{1}$, М.В. Рузіна ${ }^{1}$, М.Л. Малова ${ }^{2}$, Н.В. Білан ${ }^{1}$, О.А. Терешкова ${ }^{1}$, А.С. Гардиш ${ }^{1}$ \\ ${ }^{1}$ Національний технічний університет «Дніпровська політехніка», Дніпро, Украӥна, \\ e-mail: Zhiltsova.Irena@gmail.com \\ ${ }^{2} К П$ «івденукргеологія», Дніпро, Украӥна \\ e-mail: mamarusja@ukr.net
}

\begin{abstract}
Анотація. Викладені результати аналізу закономірностей просторового зв'язку гідротермальних золоторудних формацій 3 зонами метасоматозу та системами глибинних розломів у межах Чортомлицької зеленокам'яної структури Середньопридніпровського мегаблоку Українського щита. В результаті вивчення умов локалізації зруденіння золота з'ясовано, що золоторудна мінералізація приурочена до тектонічно порушених зон і локалізована серед метасоматично змінених порід. Гідротермальний ряд метасоматитів у Чортомлицькій зеленокам'яній структурі представлений грейзенами, пропілітами, амфібол-карбонатними метасоматитами та лиственіт-березитами. 3 метасоматитами грейзенового типу пов'язана мінералізація Au i Мо. При вивченні просторового взаємозв'язку полів метасоматитів з проявами золоторудної мінералізації та зонами глибинних розломів з'ясовано, що найбільш тісно такий взаємозв'язок виражений з системами розломів 3 азимутами простягання $0^{\circ}$ i $270^{\circ}, 17^{\circ}$ i $287^{\circ}, 77^{\circ}$ i $347^{\circ}$. Результати досліджень дозволили розробити новий пошуковий критерій, який дозволяє констатувати, що зруденіння золота в межах Чортомлицької зеленокам'яної структури просторово приурочені до метасоматитів зон розсланцювання, тріщинуватості, мілонітизації, катаклазу 3 підвищеним вмістом
\end{abstract}


сульфідної мінералізації, які локалізуються у вузлах перетину глибинних розломів першого порядку системи $77^{\circ}$ i $347^{\circ}$ iз розривними порушеннями високих порядків азимутів простягання $0^{\circ}$ i $270^{\circ}, 17^{\circ}$ i $287^{\circ}$. Результати досліджень доцільно використовувати для розробки комплексу прогнозних критеріїв і виділенняперспективних ділянок на гідротермальне зруденіння золота у межах Чортомлицької зеленокам`яної структури Середньопридніпровського мегаблоку Українського щита.

Ключові слова: глибинні розломи, метасоматити, мінералізація золота, зеленокам'яна структура, Середньпридніпровський мегаблок, гідротермальні формації.

Introduction. The study of world Precambrian gold deposits formed within the frame of greenstone structures (GSS) made it possible to state that the formation periods of gold-bearing rocks are generally synchronous throughout the planet (Nekrasov, 1988; Tyapkin, Dovbnich, 2007). This is likely due to the causes of rotagenic nature and gives reason to admit the presence of spatial regularities of worldwide distribution of gold mineralization (Kutina, 1969). Thebackgroundto the structural and tectonic factors of control and genesis of gold mineralization within the Archean cratons is still a debating point (Kent, Cassidy, Fanning, 1996; Weinberg, Hodkiewicz, Groves, 2004; Yang, Wu, Wilde, 2003). The study of distribution regularities of gold mineralization associated with the system location of faults offers additional opportunities for increasing the efficiency of the forecast and the quality of prospecting work.

Problem statement. The research conducted was intended to improve the forecast and predictive criteria for gold mineralization for incorporating into practice in metallogenic forecasting and sustainable development of the mineral raw materials base of precious metals in Ukraine.

Object of research is the factors of structural control of gold occurrences within the Chortomolyk greenstone structure (ChGSS) of the Ukrainian Shield.

Subject of research is localization patterns of goldbearing formations in relation to fault systems within the Middle Pridniprovie megablock of the Ukrainian shield.

Purpose of the research is to substantiate the patterns of structural control of zones of gold mineralization, gold-bearing formations and areas of occurrences of metasomatic processes within the Chortomolyk greenstone structure in connection with the system-hierarchical sequence of faults formation in the earth's crust.

Material and Methods. We used a technique developed by K.F. Tyapkin (Tyapkin, Gontarenko, 1990) to construct maps of faults systems on geological and geophysical data. Indicators of fault structures were used to map deep faults according to gravity and magnetic fields. The principles of conformity, fragmentation, inheritance and transformation were used to combine indicators into fault structures.
To study the patterns of spatial distribution of gold-bearing formations, a graphical comparison of the regions with the manifestation of metasomatic processes and gold minerals within the Chortomlyk GSS was carried out. Intercomparison of gold occurrences, fault systems, and sites of manifestations of metasomatic processes is carried out in a system-hierarchical sequence (from scale 1:1,000,000, through intermediate scales 1:500,000 and $1: 200,000$, to scale $1: 50,000$ and $1: 10,000$ ).

The appropriateness of the adopted methodological approach is confirmed by the successful results of previous work to determine the structural and tectonic regularities for the localization of iron ore formations relative to the above-mentioned fault systems, as well as for the study of the ore control role of fault systems in localization of hydrothermal gold ore formations (Tyapkin, 2007; Ruzina, 2009).

Results and their discussion. According to geological structure and the complex of geological formations, the Chortomolyk greenstone structure is similar to other greenstone structures within Archean cratons (David, Groves, Richard, M.Santosh, 2016; Ya-Chun Cai, Hong-Rui Fan, M. Santosh, Fang-Fang $\mathrm{Hu}$, Kui-Feng Yang, Xian-Hua $\mathrm{Li}$, 2018) and is a complexly constructed trough belt of paleovolcanism formed in the Neoarchean (Koval, Koptyukh et al., 1997). The rocks of the structure were subjected to metamorphism of greenschist, rarely epidote-amphibolite and amphibolite facies. Solidified vertical lava streams and actually existing contacts of adjacent intrusive bodies of various compositions with host metavolcanites and metasedimentary rocks form sub-vertical occurrence of rocks in most cases. Schistosity zone, numerous seams of brecciation and cataclasis, quartz, quartzcarbonate veins and veinlet zone, lens-like bodies of ferruginous quartzites are well represented in zones of contact. All of them are spatially and genetically associated with fractured sub-intrusive rocks and have a hydrothermal-metasomatic origin.

The oldest rocks of the ChGSS's "frames" are gneisses, granito-gneisses, migmatites, and amphiboletes of the Bazavluk strata with an isotopic age of 3,300 million years (Koval, Koptyukh et al., 1997). Granitoids of the Sursky complex, with an isotope age of 3,170 million years, within the frame of the greenstone structure form the root parts of 
the paleovolcanic structures of the central type, and form ring-type, crosscutting and subconcordant dyke bodies. Ultrabasites, diabases, gabbrodiabases, gabbro-diorites of the Upper Archean age, united in the Verkhovtsev complex, are widely represented within the suture tectonic fault zones and somewhat less common in the central part of the green-stone structure.

Actually, the greenstone structure copmosed of varying metamorphically altered volcanic and volcanic-sedimentary formations of the Neoarchean Konkska series. There are rocks of metamorphic metadacite-meta-andesite-metatholeiite formations in the bottom of the cross section. These rocks are slightly distributed on the periphery of the structure. The units of komatiite-tholeiite and jaspilitetholeiite formations, which in turn are overlayed by the rocks of upper metadacite-meta-andesitemetatholeiite formation, occur higher in the cross section. Metavolcanics of riolith-dacite formation is on the highest stratigraphic position. Greenstone rocks are separated from rocks of "frame" by deep faults.

Mineralization, occurrences and point anomalies of gold were discovered on the area of Chortomlyk ore district. Moreover, according to the results of previous investigations (Ruzina, 2009), a number of areal anomalies of gold and associated elements, such as silver, molybdenum, tungsten, arsenic, and others were detected in the area of the ore district.
Up-to-date and archive geological materials from the State Enterprise "Pivdenukrgeologia" and Dnipro Geophysical Expedition "Dniprogeophysica" have been studied and analyzed for the allocation of ore-hosting geological formations within the Chortomlyk GSS. Petrographic and mineralogical studies of thin sections and polished thin sections have been carried out for the study of mineral composition of structural and textural features of rocks from ore-bearing formations by geological parties and topic groups of Dnipro University of Technology,.

The schemes combining the layout of fault systems, identified by K.F. Tyapkin (Tyapkin K.F., 2007), the contours of the ChGSS shown on the geological map of the Ukrainian shield scale 1:1,000,000 (Ruzina, 2009) and the location of gold occurrences were drawn up at the first stage in order to study the conditions for the localization of hydrothermal gold mineralization.

An analysis of the location of hydrothermal gold occurrences of the ChGSS in relation to fault systems on a scale of 1:1,000,000 has been carried out in order to determine the interrelation of Chertomlyk gold mineralization with fault structures. The main criterion here is the number of gold occurrences. The location of gold occurrences in relation to fault systems is presented in Fig. 1. There is an explicit control of gold occurrences by several fault systems (see Tab. 1), which confirms the polychronism of hydrothermal gold occurrences in the Middle Pridniprovie.

Table 1. Interrelationships of gold occurrences with deep faults

\begin{tabular}{|c|c|c|c|c|c|c|}
\hline \multicolumn{5}{|c|}{ Number of gold occurrences in the fault system with strike azimuths } & Number of gold oc- \\
currences in the \\
ChGSS
\end{tabular}

The data given in the table allow us to compile the following range of coverage of gold occurrences by fault systems: $45^{\circ}$ and $315^{\circ}$ (covering $96 \%$ of occurrences) $\rightarrow 35^{\circ}$ and $305^{\circ}(100 \%) \rightarrow$ $17^{\circ}$ and $287^{\circ}(92 \%)+77^{\circ}$ and $347^{\circ}(100 \%)+62^{\circ}$ and $332^{\circ}(68 \%) \rightarrow 0^{\circ}$ and $270^{\circ}(12 \%)$. In this case, fault systems with azimuths of $77^{\circ}$ and $347^{\circ}, 35^{\circ}$ and $305^{\circ}$ are the most promising at the regional level of research.

Contrasting information is the distribution of ore-bearing nodes by fracture systems within the ChGSS (Tab. 2). According to the results of research (Ruzina, 2009), nodes of fault systems (nodes are the areas of intersection of subsystems within one fault system) determine the position of zones of maximum tectonic permeability of rocks.
The analysis of the results allowed us to reveal the number of ore-bearing nodes of fault systems within the ChGSS (Fig. 2). This criterion characterizes the relative "contribution" of each system in the tectonic activation of greenstone structure. The obtained data may determine the number of stages of ore mineralization of a particular ChGSS. Intercomparison of spatial relationships between nodes of fracture systems and gold mineralization in the ChGSS on a scale of 1:1,000,000 revealled that the closest connection of hydrothermal gold occurrences can be traced to systems of deep faults of the first and second order with strike azimuths $35^{\circ}$ and $305^{\circ}, 45^{\circ}$ and $315^{\circ}, 77^{\circ}$ and $347^{\circ}$. 
Table 2. Interrelationship of gold mineralization in the ChGSS with nodes of fault systems

\begin{tabular}{|l|l|}
\hline Fault system & Number of gold occurrences in the system node \\
\hline $35^{\circ} \& 305^{\circ}$ & 20 \\
\hline $45^{\circ} \& 315^{\circ}$ & 13 \\
\hline $62^{\circ} \& 342^{\circ}$ & - \\
\hline $77^{\circ} \& 347^{\circ}$ & 13 \\
\hline $17^{\circ} \& 287^{\circ}$ & 3 \\
\hline $0^{\circ} \& 270^{\circ}$ & - \\
\hline
\end{tabular}

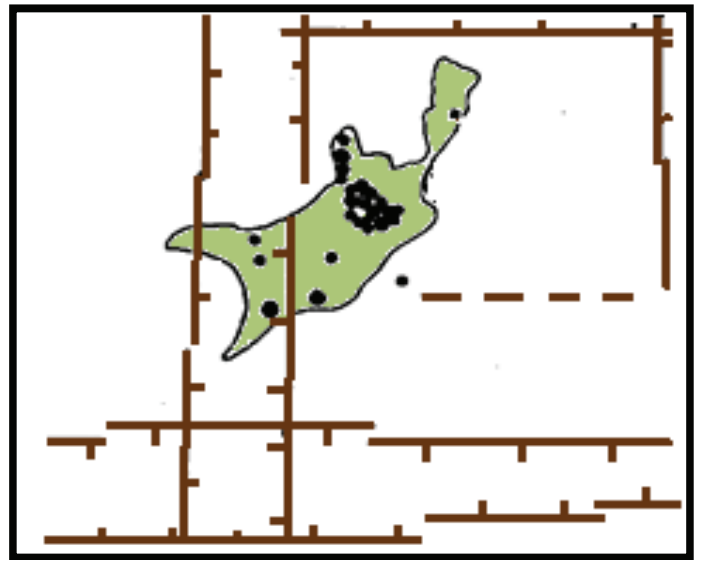

$\mathrm{a}$
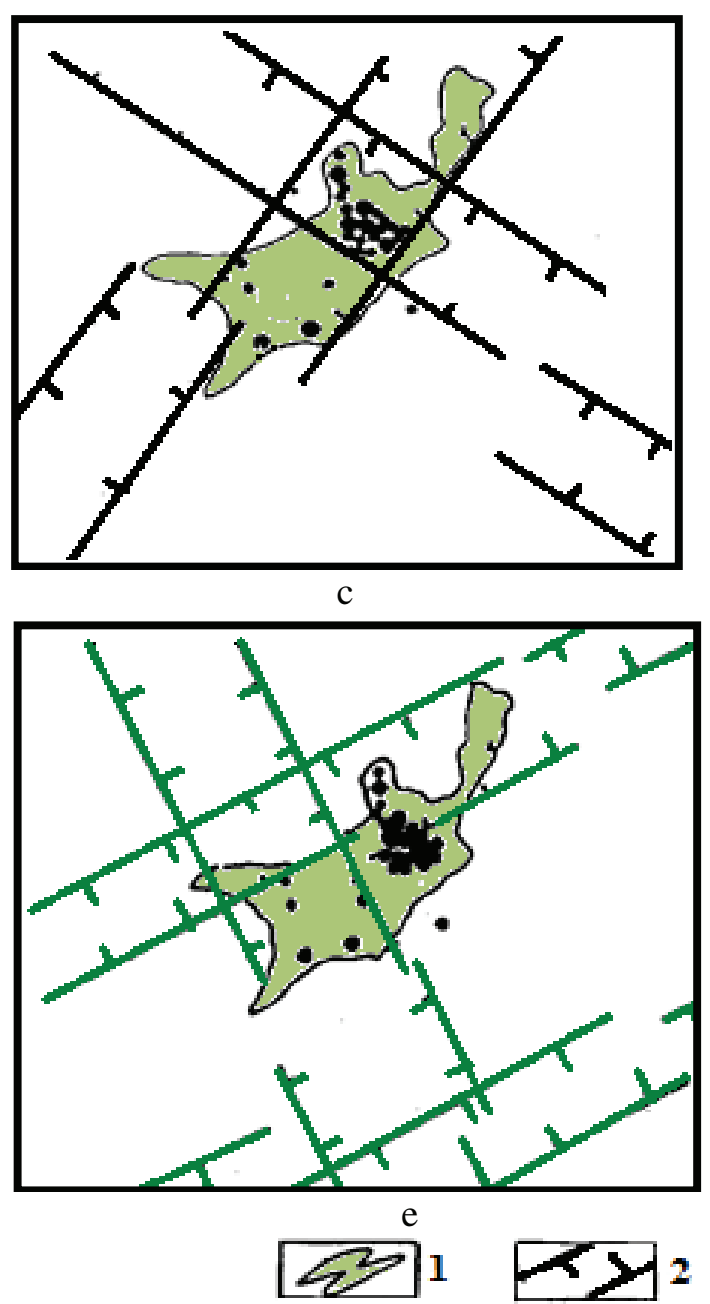

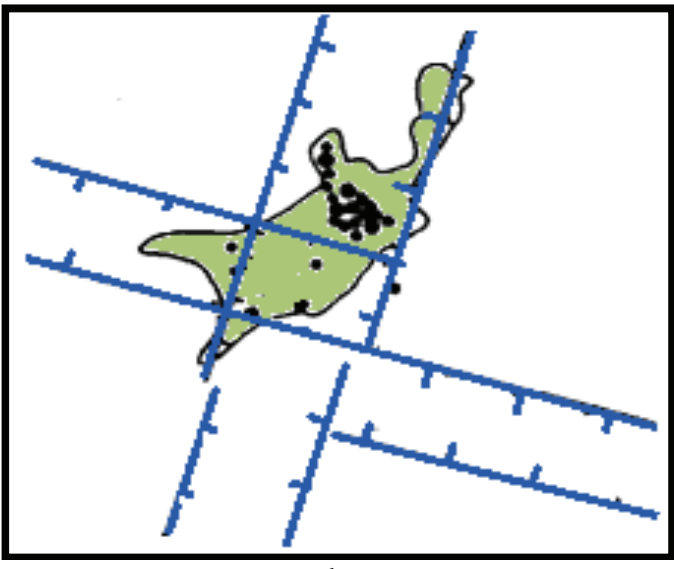

$\mathrm{b}$
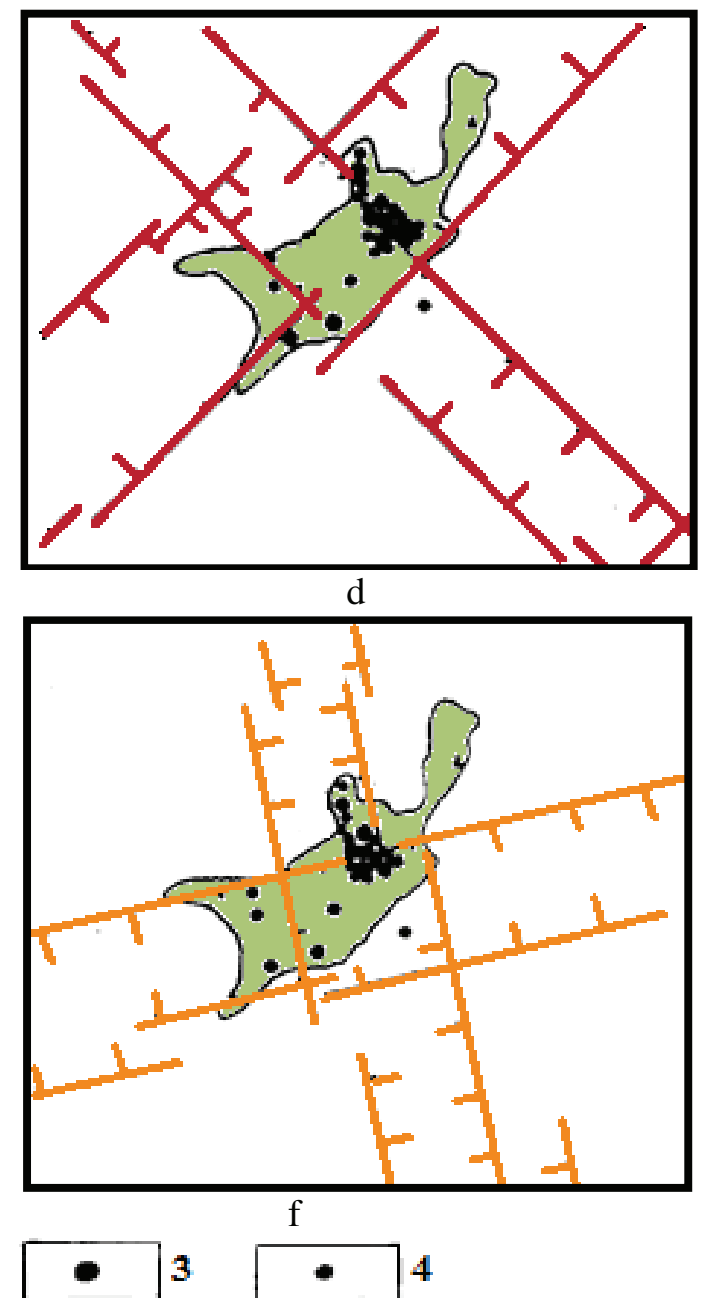

Fig. 1. Schemes for the placement of gold occurrences within the ChGSS in relation to fault systems with strike azimuths: a $-0^{\circ}$ and $270^{\circ}, \mathrm{b}-17^{\circ}$ and $287^{\circ}, \mathrm{c}-35^{\circ}$ and $305^{\circ}, \mathrm{d}-45^{\circ}$ and $315^{\circ}, \mathrm{e}-62^{\circ}$ and $332^{\circ}, \mathrm{f}-77^{\circ}$ and $347^{\circ}$, scale $1: 1,000,000 ; 1-$ contours of Chortomlyk structure, 2 - deep faults of the 1st order; 3 - gold occurrences; 4 - points of high mineralization. 
The study of localization regularities of hydrothermal ore mineralization will not be consistent without considering the spatial relationships between the geological formations of the CHGSS and fault systems, which is a priority task at the next stage of research.

The analysis of the spatial relationship between the occurrences of gold mineralization of ore-bearing formations with fault systems was per- formed in three stages. First of all, geologicalstructural schemes were compiled, the data of the geostructural map of Precambrian formations within the Middle Pridniprovie and Azov megablokcs of the Ukrainian Shield were used as geological basis. At the next stage of work schemes of six systems of faults scale 1:200,000 constructed by the authors were combined with maps.

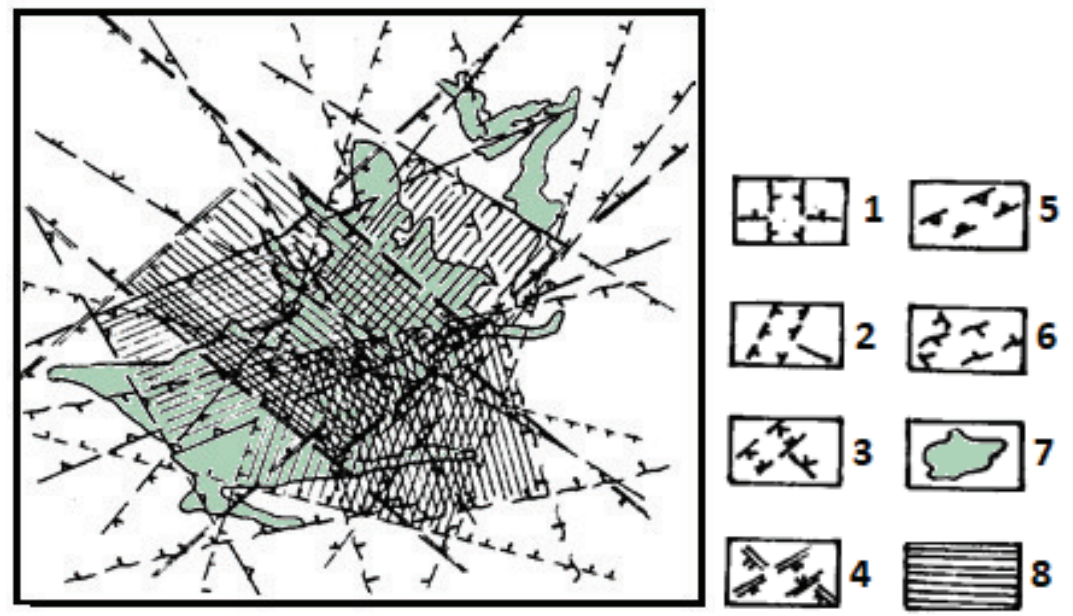

Fig. 2. The position of intersecting nodes of fault systems within the Chortomlyk greenstone structure

A number of regularities have been established as a result of the study of the distribution of gold occurrences of each ore-bearing formation in relation to fault systems. Tab. 3 shows the results of research on the distribution of gold mineralization of gold-bearing ChGSS formations in relation to deep fault systems.

Table 3. Distribution of gold mineralization of ore-bearing formations in relation to fault systems

\begin{tabular}{|c|c|c|c|c|c|c|c|}
\hline \multirow[b]{2}{*}{ Geological formations } & \multirow[b]{2}{*}{$\begin{array}{l}\text { Number of } \\
\text { gold occur- } \\
\text { rences }\end{array}$} & \multicolumn{6}{|c|}{ Number of gold occurrences in the fault system } \\
\hline & & 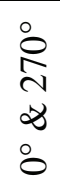 & 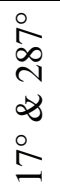 & $\begin{array}{l}i n \\
\text { on } \\
\infty \\
i n \\
\text { in }\end{array}$ & $\begin{array}{l}\text { in } \\
\text { m } \\
\infty \\
\text { in }\end{array}$ & 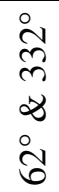 & 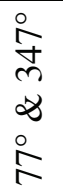 \\
\hline $\begin{array}{l}\text { Schist-jaspilite-tholeiite and } \\
\text { metakomatiite-tholeiite }\end{array}$ & 18 & 11 & 10 & 9 & 14 & 13 & 16 \\
\hline Metadacite & 2 & 1 & 1 & - & 2 & 1 & 2 \\
\hline Metarhyodacite & 2 & 1 & 1 & - & - & 1 & 1 \\
\hline Tonalite-plagiogranite & 3 & 3 & 1 & - & - & - & 1 \\
\hline Total quantity & 25 & 16 & 13 & 9 & 16 & 15 & 20 \\
\hline
\end{tabular}

Regional and local regularities of localization of hydrothermal gold mineralization in relation to faults were established as a result of intercomparison and analyzing maps of fault systems with geological maps:

1) the gold occurrences of schist-jaspilitetholeiiteand metakomatiite-tholeiite formations are spatially confined to the zones of development of all six fault systems $-0^{\circ}$ and $270^{\circ} ; 17^{\circ}$ and $287^{\circ}$, $35^{\circ}$ and $305^{\circ}, 45^{\circ}$ and $315^{\circ}, 62^{\circ}$ and $332^{\circ}, 77^{\circ}$ and $347^{\circ}$ (Tab. 3, Fig. 3).

2) the gold occurrences revealed in the rocks of the metadacite formations are completely covered by fault systems of $45^{\circ}$ and $315^{\circ}, 77^{\circ}$ and $347^{\circ}$ (Tab. 3, Fig. 4).

3) rock formation of gold mineralization of metarhyodacite formation coincides with stages of tectonic activation of fault systems $0^{\circ}$ and $270^{\circ} ; 17^{\circ}$ and $287^{\circ}, 62^{\circ}$ and $332^{\circ}, 77^{\circ}$ and $347^{\circ}$ (Tab. 3, Fig. 5);

4) rock formation of gold mineralization of tonalite-plagiogranite formation formed during the formation of fault systems $77^{\circ}$ and $347^{\circ}, 17^{\circ}$ and $287^{\circ}, 0^{\circ}$ and $270^{\circ}$ (Tab. 3, Fig. 6). 
As a result of studying the conditions of localization of gold mineralization in the ChGSS, it was found that the gold mineralization is confined to the tectonically fractured zones and is located among metasomatically altered rocks.

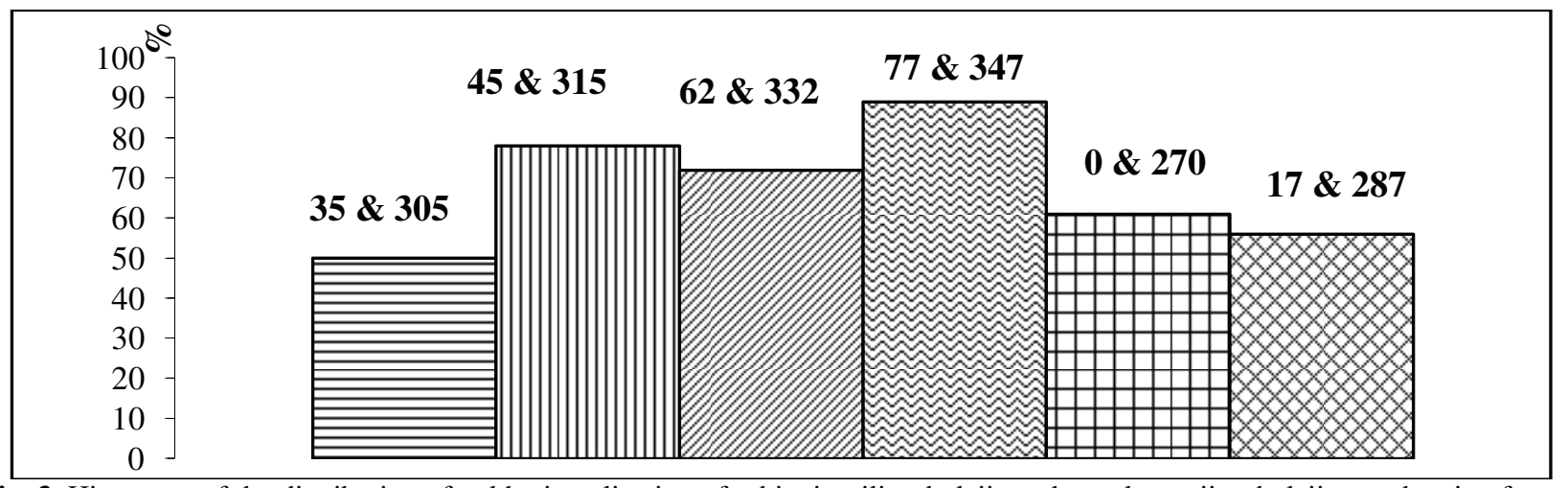

Fig. 3. Histogram of the distribution of gold mineralization of schist-jaspilite-tholeiiteand metakomatiite-tholeiite ore-bearing formations by fault systems. Marking of series of histograms is strike azimuths of faultsystems.

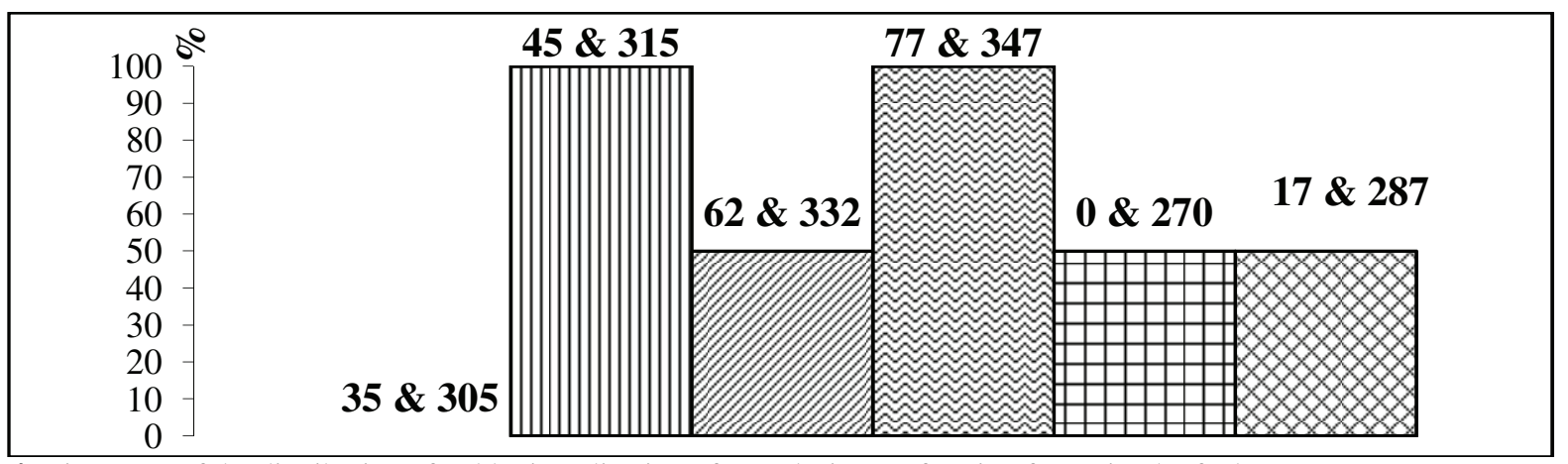

Fig. 4. Histogram of the distribution of gold mineralization of metadacite ore-forming formation by fault systems

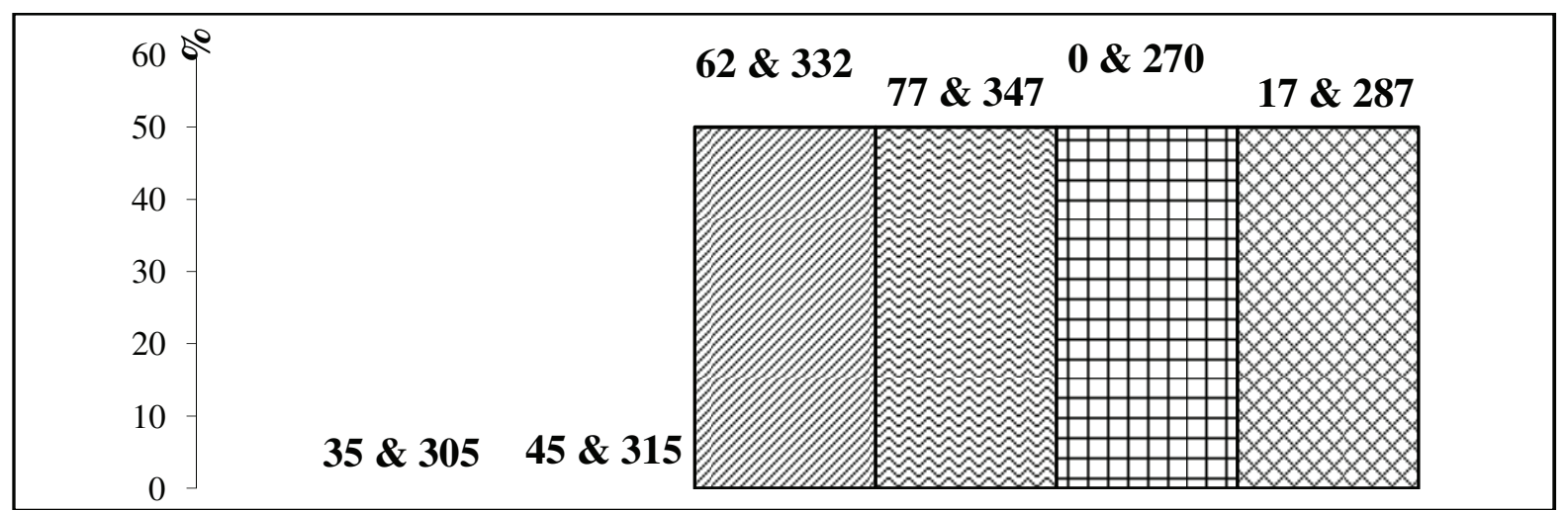

Fig. 5. Histogram of the distribution of gold mineralization of metarhyodaciteore-hosting formation by fault systems

The study of hydrothermal metasomatic formations was carried out by the authors in two stages. In the first stage, a generalization characteristic of the material composition of various types of ore metasomatites of the ChGSS is compiled taking into account the data (Ruzina M.V., 2009) and based on the results of the study by the authors of the collections of polished thin sections and thin sections of metasomatic rocks.

The ore content of metasomatites is studied by the authors on the basis of these data
(ZhiltsovaI.V., RuzinaM.V., SvistunV.K., 2015), and summarized in the Tab. 4.

The hydrothermal series of metasomatites in the Chortomlyk green-stone structure is represented by greisens, propyllites (Fig. 7), amphibolecarbonate metasomatites and listvenite-beresites (Fig. 8-10).

The mineralization of $\mathrm{Au}$ and $\mathrm{Mo}$ is associated with metasomatites of the greisen type. The remaining three formations exhibit a similar metal content, represented by $\mathrm{Au}, \mathrm{Cu}$ and $\mathrm{Zn}$. 


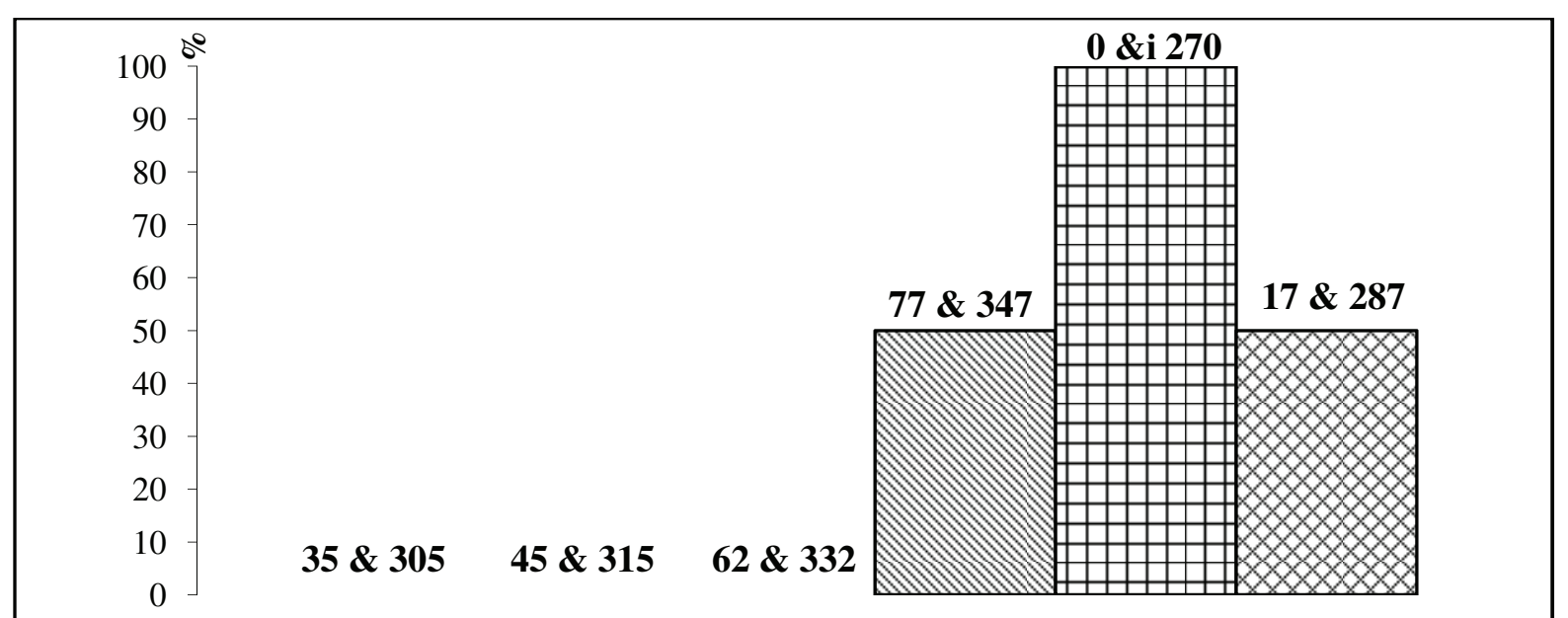

Fig. 6. Histograms of the distribution of gold mineralization of tonalite-plagiogranite ore-hosting formation by fault systems

Table 4. Metasomatic formations of ChGSS containing ore mineralization

\begin{tabular}{|c|c|}
\hline Metasomatic formation (rocks) & Type of ore mineralization \\
\hline Quartz-muscovite (greisens) & $\mathbf{A u}, \mathrm{Mo}$ \\
\hline Epidote-chlorite-amphibole-albite (propyllites) & $\mathbf{A u}, \mathrm{Cu}, \mathrm{Zn}$ \\
\hline Sericite-carbonate (listvenite-beresites) & $\mathbf{A u}, \mathrm{Cu}, \mathrm{Zn}$ \\
\hline Amphibole-carbonate & $\mathbf{A u}, \mathbf{C u}, \mathbf{Z n}$ \\
\hline
\end{tabular}

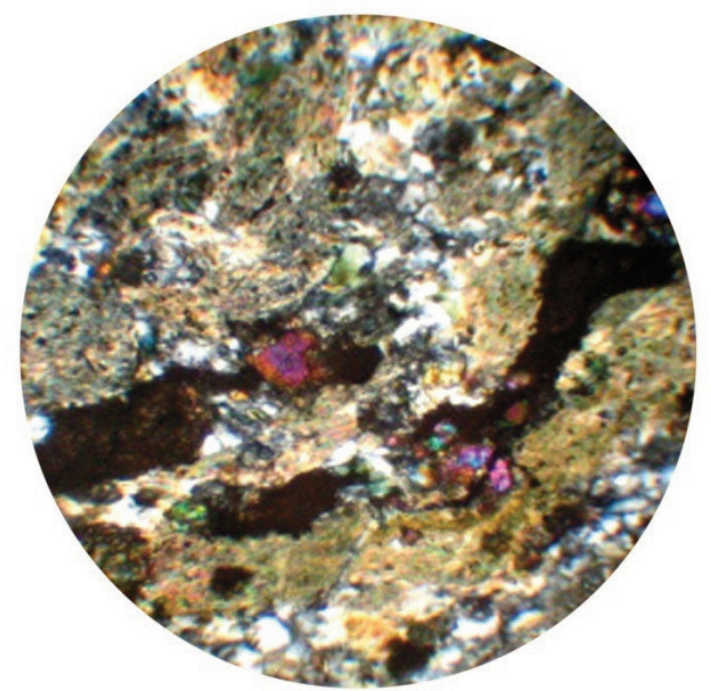

Fig. 7. Epydot-chlorite-albite propyllite. Thin section. Cross-polarized light, 90x zoom.

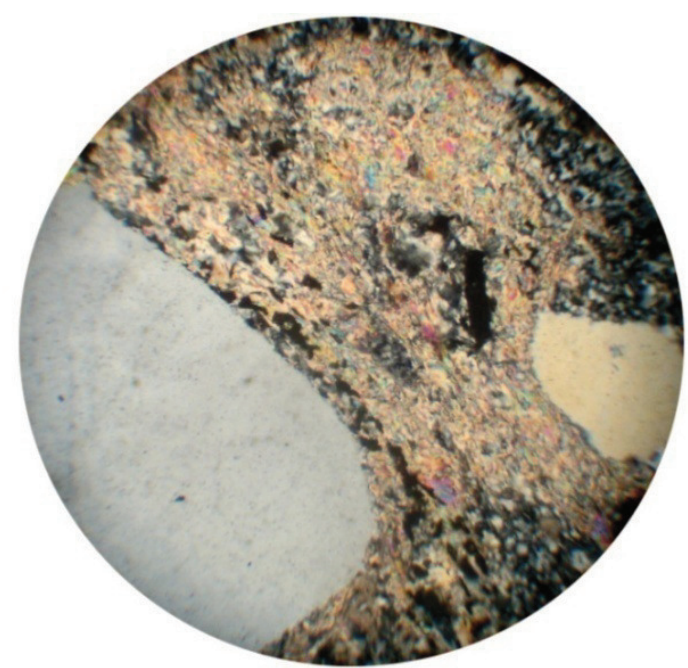

Fig. 8. Listvenite-beresites in rhyolite. Thin section. Cross-polarized light, 90x zoom. 


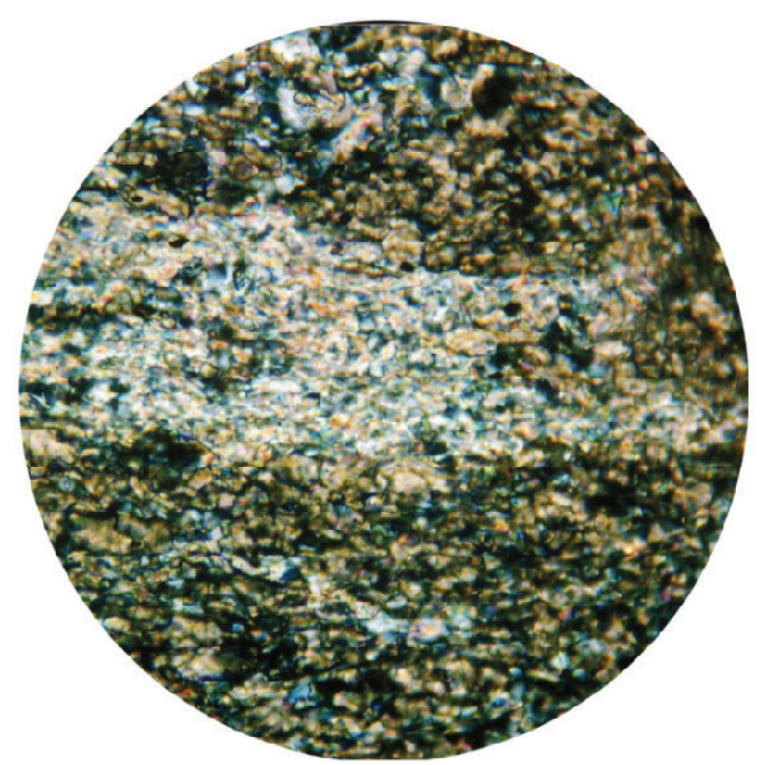

Fig. 9. Carbonate metasomatites. Thin section. Cross-polarized light, 90x zoom.

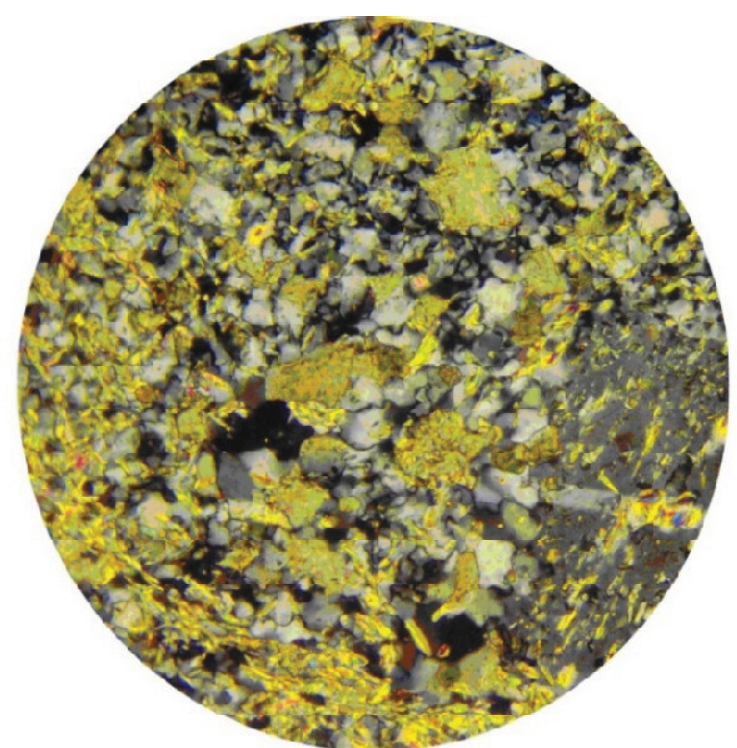

Fig. 10. Listvenite-beresites in rhyolite with reticulate location of newly formed carbonate-sericite aggregates. Thin section. Crosspolarized light, 90x zoom.

Conclusions In studying the spatial relationship between the fields of metasomatites with the gold occurrences and fault zones, it was found out that the most closely related relationship is manifested with fault systems with strike azimuths $0^{\circ}$ and $270^{\circ}, 17^{\circ}$ and $287^{\circ}, 77^{\circ}$ and $347^{\circ}$.

The results of the studies allowed us to develop a new prospecting criterion and consequently to state that the gold mineralization within the Chortomlyk greenstone structure is spatially confined to metasomatites of the zones of schistosity, fracture, millonitization, cataclase with high content of sulfide mineralization. These zones are localized in nodes of intersecting faults of the first order of the system $77^{\circ}$ and $347^{\circ}$ with the faults of high orders of azimuths $0^{\circ}$ and $270^{\circ}, 17^{\circ}$ and $287^{\circ}$.

The results of the research should be used to develop a set of predictive criteria for gold miner- alization and the allocation of promising sites in the design of exploration in the territory of the Middle Pridnieproviemegablock of the Ukrainian Shield.

\section{References}

David I. Groves, Richard J. Goldfarb, M. Santosh, 2016. The conjunction of factors that lead to formation of giant gold provinces and deposits in non-arc settings. Geoscience Frontiers. 7. 3, 303-314. https://doi.org/10.1016/j.gsf.2015.07.001

Kent A., Cassidy K., Fanning C., 1996. Archean gold mineralisation synchronous with the final stages of cratonisation, Yilgarn Craton, Western Australia. Geology. 24. 10, 879-882. https://doi.org/10.1130/00917613(1996)024<0879:AGMSWT>2.3.CO;2

Koval V.B., Koptyukh Yu.M., Yaroschuk M.A., Fomin Yu.A., Lapusta V.F., 1997. Zolotorudnyie 
mestorozhdeniya Ukrainskogo schita [Gold deposits of the Ukrainian shield]. Geology of Ore Deposits. 39. 3, 229-246.(in Russian).

Kutina Jan., 1969. Hydrothermal ore deposits in the western united states: The new Concept structural control of distrsbution. Science, 165. 3, 11121119.

NekrasovE.M., 1988. Zarubezhnyie mestorozhdeniya zolota [Foreign gold deposits]. Moscow: Nedra. 286. (in Russian).

RuzinaM.V., 2009. Zakonomernosti rasprostraneniya i rudonosnost polihronnyih metasomaticheskih formatsiy Srednepridneprovskogo megabloka Ukrainskogo schita [Regularities of distribution and ore content of polychromous metasomatic formations of the Middle Pridnieprovie megablock of the Ukrainianshield. Monograph. Dnepropetrovsk. National Mining University. 158. (in Russian).

Tyapkin K.F., 2007. Novaya rotatsionnaya gipoteza strukturoobrazovaniya i metallogeniya [New rotational hypothesis of structure formation and metallogeny]. Reports of the National Academy of Sciences of Ukraine. 2007. 3, 128-132.(in Russian).

Tyapkin K.F., Dovbnich M.M., 2007. Novaya rotatsyonnaya gipoteza strukturoobrazovaniya i ee geologo-matematicheskoye obosnovaniye [New Rotational Hypothesis of Structure Formation and Its Geological-Mathematical Substantiation], Donietsk, Knowledge. 342.(in Russian)
Tyapkin K.F., Gontarenko V.N., 1990. Sistemyi razlomov Ukrainskogo schita [Fault systems of the Ukrainian shield]. Kiev: Nauk. dumka 184. (in Russian).

Weinberg R.F., Hodkiewicz P.F., Groves D.I., 2004. What controls gold distribution in Archean terranes? Geology. 32. 7, 545-548. doi: 10.1130/G20475.1.

Ya-Chun Cai, Hong-Rui Fan, M. Santosh, Fang-Fang $\mathrm{Hu}$, Kui-Feng Yang, Xian-Hua Li, 2018. Decratonic gold mineralization: Evidence from the Shangzhuang gold deposit, eastern North China Craton. Gondwana Research. 54. 1-22. https://doi.org/10.1016/j.gr.2017.09.009

Yang J.H., Wu F.Y., Wilde S.A., 2003. A review of the geodynamic setting of large-scale Late Mesozoic gold mineralization in the North China Craton: an association with lithospheric thinning. Ore Geology Review, $23 . \quad 125-152$. https://doi.org/10.1016/S0169-1368(03)00033-7

ZhiltsovaI.V., RuzinaM.V., SvistunV.K., 2015. Zakonomernosti raspredeleniya gidrotermalnyih zolotorudnyih formatsiy zelenokamennyih struktur Srednepridneprovckogo megabloka Ukrainskogo schita otnositelno sistem glubinnyih razlomov [Regularities in the distribution of hydrothermal gold formations of greenstone structures of the Middle Pridnieprovie megablock of the Ukrainian Shield with respect to the systems of deep faults]. Monograph. Ministry of Education and Science of Ukraine, NMU. D.: NGU. 131. (in Russian). 